ORNL/M--1341

DE9 1005773

Monthly Progress Report

\title{
Building Thermal Envelope Systems and Materials (BTESM) \\ Progress Report for DOE Office of Buildings Energy Research
}

November 1990

Compiled by Gabrielle Burn for

Jeffrey E. Christian, Program Manager

Energy Division

\author{
Prepared by the \\ Oak Ridge National Laboratory \\ Oak Ridge, Tennessee 37831 \\ operated by \\ Martin Marietta Energy Systems, Inc. \\ for \\ U.S. DEPARTMENT OF ENERGY \\ under contract DE-ACO5-840R21400
}


CONTENTS

I. BUILDING THERMAL ENVELOPE SYSTEMS AND MATERIALS (BTESM) Page

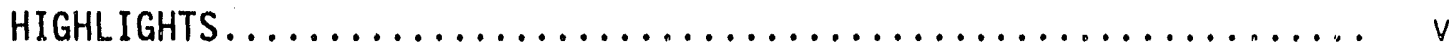
ABSTRACT ..................................... vit

A. IMPLEMENTATION

1. Administration/Technical Support/Selected Projects...... 1

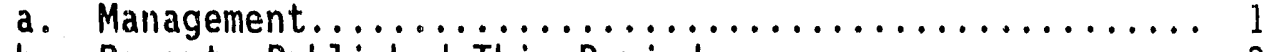

b. Reports Published This Period................ 3

c. Conferences and Meetings of Interest............. 4

d. Consultants Report......................... 5

B. BUILDING MATERIALS PROGRAM

Task B1. Advanced Materials Development

1.1 Evacuated Powder Pane1s...................... 8

1.2 Selective Surface Coatings........................... 9

1.3 Joint Project with the Foam Industry............. 10

Task B2. Existing Materials/Test Procedure

2.1 Test Procedure for High R, Super Insulations......... 11

2.2 ORNL Support Services to Industry \& DOE............ 12

Task B3. Building Materials Program Management Support

3.1 Management - ORNL............................ 14

C. BUILDING ENVELOPE SYSTEMS

WALL PERFORMANCE

1. Thermal Mass Simplified Design Tool Assessment......... 16

2. Dynamic Evaluation of Thermal Bridges................ 17

3. Validation of Moisture-Transfer Mode $\ldots \ldots \ldots \ldots . \ldots 18$

C. BUILDING ENVELOPE SYSTEMS (cont'd)

ADVANCED WALL SYSTEMS

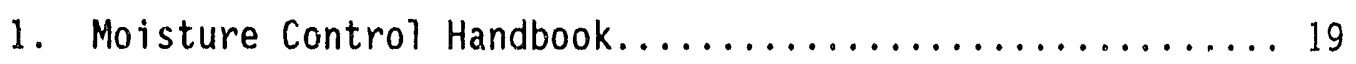




\section{FOUNDATION SYSTEMS}

1. Building Foundations Research Agenda............... 20

2. Slab Foundation Benchmark Model................. 20

3. Foundation Thermal Performance Simplified

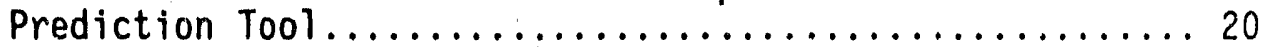

ROOF SYSTEMS

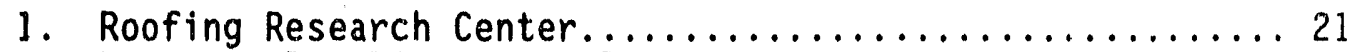

2. Large Scale Climate Simulator................... 22

3. IEA Annex on Low Slope Roof Systems............... 22

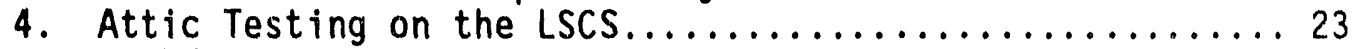

5. Field Testing of Isocyanurate Foams with Alternate

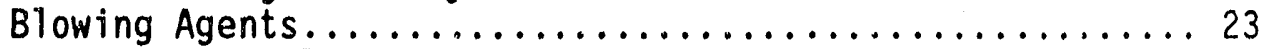

6. Koof Mechanical Properties Research Apparatus.......... 24

7. Roofing Industry Committee on Wind Issues........... 24

D. COOPERATIVE PROJECTS

1. Cooperative Industry, Government Research Project on Alternative Blowing Agents................... 25 


\title{
HIGHLIGHT
}

\section{SECOND SYMPOSIUM ON INSULATION MATERIALS-- TESTING AND APPLICATIONS}

October 10-12, 1991

Gatlinburg, Tennessee

SPONSORED BY ASTM COMMITTEE C16

\section{ON}

\section{THERMAL INSULATION}

Call for Papers:

April 1, 1990

Abstracts Due:

August 1, 1990

Abstract Acceptance Notification: September 1, 1990

Manuscripts Due:

STP f vailable:

January 2, 1991

October 10, 1991

\begin{abstract}
Session I:
Session II:

Session III:

Session IV:

Session V:

Session $V$ :

Session VII:

Session VIII:

Session XX:

Session $X$ :
\end{abstract}

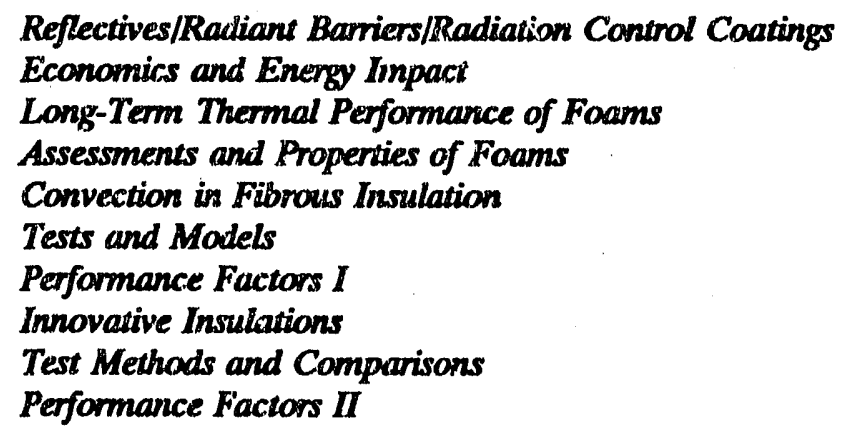

For more information, please contact Symposium Co-Chairmen:

Ron S. Graves

Oak Ridge National Laboratory

Post Office Box 2008

Building 4508

Oak Ridge, TN 37831-6092

615/574-5978

FAX 615/574-7721
Don C. Wysocki

Mobay Corporation

Penn Lincoln Parkway West

Pittsburgh, PA 15205

412/777-2574

FAX 412/777-2758 
Building Thermal Envelope Systems and Materials (BTESM) Progress Report for DOE Office of Buildings Energy Research

\section{ABSTRACT}

The Monthly Report of the Building Thermal Envelope Systems and Materials (BTESM) Program is a monthly update of both in-house ORNL projects and subcontract activities in the research areas of building materials, wall systems, foundations, roofs, and building diagnostics. Presentations are not stand-alone paragraphs every month. Their principal values are the short-time lapse between accomplishment and reporting and their evolution over a period of several months. 


\section{BUILDING THERMAL ENVELOPE SYSTEMS AND MATERIALS (BTESM)}

\section{A. IMPLEMENTATION}

\section{Administration/Technical Support/Selected Projects}

This task includes overall management for the BTESM Program with the emphasis on assuring that individual R\&D projects are performed via the best available expertise whether it be at universities, private labs, professional associations, or national labs (including ORNL). Also included are: implementation of major conferences, workshops and seminars, assurance of BTESM staff participation in committee work (BTECC, NIBS, ASTM, ASHRAE, etc.), BTESM National Program planning jointly with the total building community, technical support to DOE, and oversight of selected technical projects not delegated to other tasks.

\section{a. Management (Jeffrey E. Christian/Pat M. Love, ORNL)}

A new format for monthly reporting of interest items to industry has been approved and will be implemented with the January progress report. The highlight or interest items will be written up by each project leader and submitted to the entire distribution of the current mailing list. A detailed progress report will be issued only to the DOE sponsors.

A11 BTESM program areas are awaiting budget approvals from DOE/HQ.

Mr. John C. Goldsmith, DOE/HQ, is our new Walls and Foundations Research Program Manager. He is replacing Sam Taylor, who has done a fine job in guiding this research for about three years. Sam will now be concentrating his efforts on windows and daylighting.

Two Joint Work Statements for Cooperative Research and Development Agreements (CRADAs) have been approved by OKO. One is with the Polyisocyanurate Insulation Manufacturers Association (PIMA) to determine the thermal performance of experimental, prototypical foam insulation boardstock produced by industry but conducting field and laboratory experiments. This testing will utilize the Roof Thermal Research Apparatus (RTRA) and the Roof Mechanical Properties Research Apparatus (RMPRA), both of which are part of the Roof Research Center facilities at ORNL. The other one is with the Cellu7ose Industry Standards Enforcement Program (CISEP) for evaluating the thermal performance of cellulose insulation in a conventional attic. This research will utilize the attic mockup facility and the Large Scale Climate Simulator (LSCS) at the Roof Research Center. Negotiations are under way for a third CRADA with Foamseal Urethane Technology to establish a project to provide thermal performance benefits of ceiling panels with a polyurethane adhesive manufactured by Foamseal and used in the construction of manufactured housing. 
Thermal Performance of the Exterior Envelopes of Buildings $V$ Conference: The next planning meeting for this conference will be held January 21, 1991, from 9 to 12 noon in Room 513 of the New York Hilton. At this time, a presentation will be made for site selection and final confirmation of chairs. A tentative program plan will be presented for comment and review. Other discussion will include topics for sessions.

Second Symposium for Insulation Materials - Testing and Applications: This symposium, sponsored by ASTM Committee C 16, will be held October 10-12, 1991, in Gatlinburg, Tennessee, at the

Holiday Inn. Registration forms will be available in January. This is a busy time for Gatlinburg (peak Fall colors), located at the foot of the Great Smoky Mountains, so make your plans and reservations early. For more information, contact Co-Chairman Ron S. Graves at

(615) 574-5978. See the highlight page for session topics.

IEA Activities: David Harrje and Jianshun Zhang (University of I17inois) attended the Sixth Fxperts Meeting of Annex 20, Airflow Patterns within Buildings, in Nice, France. Major topics included measurement of low air velocity in the occupied zone, the measurement of air velocities within the flow boundary layer over the ceiling of wall surfaces, modeling diffuser air jets, and nonsymmetry and low turbulence characteristics of the ventilation flow. The Bioenvironmental Engineering Research Laboratory (BERL) located at the University of Illinois has the only Room Ventilation Simulator available within the participating countries to compare simulation results. Their reports are available from this office.

Jack Warner of the ACEC Research and Management Foundation participated in the Program on Energy Conservation in Buildings and Community Systems, Future Building Forum 2025. The objective of this forum is to develop plans for new areas of investigation that affect various energy, environmental, economic, and technological trends on buildings of the next 40 years. This was the third in a series of meetings involved in identifying and encouraging research, based on long-term issues, to ensure that future buildings will satisfy the society needs without jeopardizing the prospects of future generations. His report is al so available from this office.

\section{EVENTS}

November 12

Joe Hagan, Jim Walter Research, visited ORNL. He inspected the roof of the ESRA with George Courville ana Jeff Christian. His impression was that, in general, both the built-up roof section and the single ply sections looked pretty good after a hot summer season.

November 14-15 Jeff Christian attended an Industrial Research Institute study group, St. Petersburg, Florida. 
November 17

Bob Kripowicz, Staff Assistant, Energy Subcommittee on Interior and Related Agencies, was briefed on, "Thermal Performance of Residential Attic Insulation at the Roof Research Center," by Jeff Christian at ORNL.

November 20

Bob Wendt and Jeff Christian provided a tour of the Large Scale Ciimate Simulator, Roof Thermal Research Apparatus, and the Envelope Research Apparatus to 50 high school science class students.

November 27

Jeff Christian appeared on the local TV evening news as part of an ORNL press release announcing the first signed Cooperative Research and Development Agreement (CRADA) with private industry.

b. REPORTS PUBLISHED THIS PERIOD

ORNL/CF-90/292: 1990 Loose-Fill Insulation Interlaboratory Comparison Test Plan (October 1990). 


\section{c. CONFERENCES AND MEETINGS OF INTEREST*}

\section{$\underline{1990}$}

December 10-12: Third Brazilian Thermal Science Meeting, ENCIT-90, to be held in Itapema, SC, Brazil. For more information, contact Professor Alvaro T. Prata, Department of Mechanical Engineering, Federal University of Santa Catarina, P.0. Box 476, 88049 - Fiorianopol is-SC, Brazil, or call (0482) 335166, FAX (0482) 331519, or Telex 481317 FUEG BR.

\section{$\underline{1991}$}

January 17-20: NAHB Annual Convention, Atlanta, Georgia, Georgia World Congress Center.

January 19-23: ASHRAE 1990 Winter Meeting, to be held in New York, NY. For more information, contact Judy Marshall or Jan Young, ASHRAE Meetings, 1791 Tullie Circle, NE, Atlanta, GA 30329, or call (404) 636-8400.

April 17-19: Third International Symposium on Roofing Technology, sponsored by the National Institute of Standards and Technology; U.S. National Roofing Contractors Association; Canadian Roofing Contractors Association; National Research Council of Canada; International Waterproofing Association; CIB, and RILEM. The symposium will be held at the Montreal Convention Centre, Montreal, Quebec, Canada. For more information, contact Walter Rossiter, NIST, Center for Building Technology, Building 226, Room B-348, Gaithersburg, MD 20899, or call (301) 975-6719, FAX (301) 975-4032, TELEX TRT 197674 NIST WT.

October 10-12: Second Symposium on Insulation Materials--Testing and Applications, sponsored by ASTM Cominittee C 16, to be held in Gatlinburg, TN. For more information, contact Symposium Co-Chairmen: Ron S. Graves, Oak Ridge National Laboratory, P.0. Box 2008, B1dg. 4508, Oak Ridge, TN 37831-6092, (615) 574-5978; or Don C. Wysocki, Mobay Corporation, Penn Lincoln Parkway West, Pittsburgh, PA 15205, (412) $777-2574$.

\section{2}

December: Thermal Performance of the Exterior Envelope of Buildings $V$, to be held in the Florida area. Sponsors include DOE, ASHRAE, and BTECC. For more information, contact Pat M. Love, Co-Chairperson, Oak Ridge National Laboratory, P.0. Box 2008, Oak Ridge, Tennessee 37831-6070, or cal1 (615) 574-4346.

*Please send notices to Gabrielle Burn. 
d. CONSULTANTS

\section{ACEC RESEARCH AND MANAGEMENT FOUNDATION}

Jack R. Warner

President

Washington, D.C. 20005

Subcontract ORNL/SUb-SE077/3

Deliver by: 05-31-90

A new contract is pending. 


\title{
BTECC WORKSHOPS AND FEASIBILITY STUDY \\ BUILDING THERMAL ENVELOPE COORDINATING COUNCIL NATIONAL INSTITUTE OF BUILDING SCIENCES
}

\author{
Bruce E. Vogelsinger \\ National Institute of Building Sciences \\ Washington, D.C. 20005 \\ Subcontract ORNL/SUb-SC111/9 \\ Deliver by: $12-31-90$
}

This contract has three tasks:

1. Feasibility of a Tracking System on Current Research and Publications on Building Thermal Envelopes.

A detailed scope of work was developed and distributed to potential subcontractors. Three proposals were reviewed and a subcontract was awarded to Energy Design Associates, Inc., Ansonia, New York. Work is under way, and the Materials RCC Committee of BTECC met on June 4 and reviewed the work of the subcontractor. A three-person review committee has been appointed. An interim report was submitted to the committee for review and comment on october 22. The report was reviewed by the Materials RCC Committee at a November 6 meeting. Comments on the draft report have been transmitted to Energy Design Associates and the final report is scheduled to be completed on December 28.

2. Workshop on Building Heat Flow Measurements.

The workshop was held at the Cold Regions Research and Engineeririg Laboratory, Hanover, NH on May 22-23, 1990. Twenty-three people attended the workshop. Papers from the authors were due September 1, 1990. The last paper was received in November. Style editing has been completed, and the papers have been returned to the authors for review and final typing. Camera-ready papers are due back from authors on November 30. Some papers are still outstanding, and the authors have been urged to return the papers as soon as possible. Publication of the proceedings is now scheduled for February 28, 1991.

3. Workshop on Preventing and Repair of Condensation Damage in New and Existing Housing.

The planning and conduct of this workshop has been assigned to BTECC's Research Coordinating Committue on Moisture Control. Erv Bales, New Jersey Institute of Technology, and Bill Rose, University of 11 linois, volunteered to co-chair the workshop. The RCC met on November 6 and has developed a draft program and selected the data of May 20-21, 1991, for the workshop. A proposed program with speakers has been distributed to the committee for comments by December 5. Locations being considered for the workshop are Chicago and Washington, D.C. 
TASK B. BUILDING MATERIALS PROGRAM

The Building Materials Program includes work done at ORNL and work done by others on DOE-funded projects. The following pages include project reports for three areas:

\section{B1. ADVANCED MATERIALS DEVELOPMENT}

1.1 Evacuated Powder Panels

1.2 Selective Surface Coatings

1.3 Joint Project with the Foam Industry

B2. EXISTING WATERIALS/TEST PROCEDURE

2.1 Test Procedure for High R, Super Insulations

2.2 ORNL Support Services to Industry \& DOE

\section{B3. BUILDING MATERIALS PROGRAM MANAGEMENT SUPPORT}

3.1 Management - ORNL 
BUILDING

MATERIALS

PROGRAM

TASK B1. AOVANCED MATERIALS DEVELOPMENT

\subsection{EVACUATED POWDER PANELS}

\subsubsection{Polymer Barrier Materials}

T. G. Kollie

Dak Ridge National Laboratory

Oak Ridge, Tennessee 37831-6092

We attended the November meeting of the insulation committee of the Appliance Research Cunsortium (ARC), which is a wholly owned subsidiary of the American Home Appliance Manufactures (AHAM) Association. The ARC wants to develop a procedure to predict the 1 ifetime of vacuum insulation. We discussed a modified scatement of Work (SOW) outlining our approach and the projected cost to the ARC. We will discuss a detailed SOW with the insulation committee at their December meeting in Washington, D.C.

We attended "PACK EXPO '90" at McCormick Place in Chicago, I11 inois. Packaging equipment and materials were exhibited by vendors.

Information gained assured us that existing materials can be "converted" into polymer composites that will meet the lifetime requirements for PEP barrier materials. Also, equipment is available for automation of a PEP fabrication. Valuable contacts were made that should allow construction of PEP fabrication facility at ORNL within the next few months, depending on equipment Jelivery.

The first rough draft of our summary report that reviews the ORNL. efforts in panel technology is being reviewed by the authors to prepare draft two for internal review by peers.

\subsubsection{Fabrication of Evacuated Panel Insulation Using Thin Glass Sheets as the Barrier Materiai \\ Glicksman, Lanciani, Page, Moreno, Zammit Massachusetts Institute of Technology Cambridge, Massachusetts 02139}

ORNL/SUb-09099/18

Completed glass shells are nuw being produced on a regular basis. In order to produce a whole shell with no cracks or holes, it was necessary to round all the corners and file down most edges on the mold. This does not, however, greatly effect the overall shape of the she11, which is still a $3 \times 3 \times .5 \mathrm{in.}^{3}$ rectangular brick. 
Now that the glass shells are available, work is beginning on filling the shells with a suitable amount of silica powder. When using glass shells as an encapsulant for evacuated panels, it is necessary that the silica powder itself support the glass shell. Thus, it is important that the powder completely fill the glass shell before it is sealed under vacuum. Then atmospheric pressure may be reintroduced, only at high temperatures, so that the glass may flow to conform to the shape of the powder.

Currently, tests are being done using both a pre-compressed powder brick and loose powder. In the first case, a powder brick of desired density is produced using a mechanical press and then placed into the glass she11. This method had proved successful in earlier experiments with the glass panels. However, due to the slightly rounded edges and corners of the glass shell, $\vdots t$ is difficult to get the shell to conform to the shape of the powder brick. The second method involves filling the glass shell with loose powder and then compressing it under vacuum. This method is very promising and results of the tests should be available shortly.

\title{
1.2 SELECTIVE SURFACE COATINGS
}

\subsubsection{Radiation Control Coatings}

\author{
Robert W. Anderson \\ Robert W. Anderson and Associates, Inc. \\ Boulder City, Nevada 89005
}

\section{ORNL/SUb-SE791/7}

Analyses of computerized simulations of the annual thermal performances of roofs with and without RCCs were continued for five climatic areas. The analyses show the effect of RCCs on (a) heating and cooling loads for roofs with various levels of thermal insulation, and (b) roof surface temperatures and ceiling temperatures.

Test data from the ORNL RTRA summer test of RCCs were received this month, and measured heat flow and roof surface and ceiling temperature data were compared to the values calculated with the BLAST program. Preliminary results show excellent agreement between the measured and calculated roof surface temperatures; however, there are significant differences between the measured and calculated values for heat flow and ceiling temperatures. Possible causes for these differences are being explored in both the calculiution methods and the testing procedures.

Five RCC samples were prepared and submitted for one year equivalent solar exposure testing. The objective of the testing is to assess the effects of long-term solar exposure on reflectance properties. Testing is scheduled for completion in April 1991. 


\title{
1.3 JOINT PROJECT WITH FOAM INDUSTRY
}

\subsubsection{ORNL Activities}

\author{
R. S. Graves, D. W. Yarbrough, and T. G. Kollie \\ Oak Ridge National Laboratory \\ Dak Ridge, Tennessee 37831-6092
}

The minutes of the Cooperative/Government Program Steering Commititee meeting held on October 4, 1990, in Orlando, Florida, were distributed to participants and a copy of the third draft of, "Laboratory iest Results on the Thermal Resistance of Polyisocyanurate Foam Board Insulation Blown with CFC-11 Substitutes - A Cooperative Industry/ Government Project" (ORNL/TM-11645), was attached for review.

The first meeting of a task group to develop an aging model for foam aging was held on November 29, 1990, in conjunction with the CFCAlternatives Conference in Baltimore. The group's objective is a computer code for the thermal performance of foamb:ard insulations with time. The validation of one-dimensional calculations, reconciliation of $1 \mathrm{ab}$ and field measurements, extension of calculations to three dimensions, and inclusion of facing material were identified as priority topics.

Thermal conductivity tests were completed on the RTRA panels which were blown with CFC-11, HCFC-123, and HCFC-141b (two membranes). These panels are approximately 520 days of age and have now experienced about 430 days of RTRA exposure. Data were obtained in both the Unguarded Thin-Heater Apparatus (UTHA) and the ORNL heat flow meter apparatus (HFMA). These data can be represented with the expression $k=A+B+$ $c / t$, and the absolute average percent deviation does not exceed $0.7 \%$ for any data set. The maximum deviation of any single datum is $1.4 \%$. The order of the thermal conductivity (CFC-11, HCFC-123, HCFC-141b) has not changed. The heat flux transducers were recalibrated and were within $1 \%$ of previous values.

Draft three of, "Interlaboratory Comparison of Four Heat Flow Meter Apparatuses on Planed Polyisocyanurate Boards Foamed with CFC-11" (ORNL/TM-11720), was prepared and now contains new values for thermal conductance. The document has been sent to all authors and to four reviewers. 


\title{
1.3.2 Invest"gation of the Substitution of Environmentally Acceptable Blowing Agents in Foam Insulation: Means To Achieve Equivalent or Approved Energy Efficiency
}

\author{
Glicksman, Lanciani, Page, Moreno, Zammit \\ Massachusetts Institute of Technology \\ Cambridge, Massachusetts 02139
}

ORNL/SUb-09099/18

$\mathrm{KBr}$ pellets with coated micropowder samples have been weighed out and prepared. FTIR spectrometer analys is is under way. Yorkshire Nachem, Dupont, GE, and Aldrich companies have donated core micropowders that are undergoing hybridization at Bepex Corporation. The process coats the core powders with graphite donated by the Cabot Corporation. Numerical analysis in combination with the FTIR spectrometer experimentation will determine the proportion of micropowders that should be added during foaming. Dow Chemical Company has agreed to add candidate micropowders to foam. Thirteen toner samples are also being considered for addition to foam.

Testing has begun on foams that were supplied to Melissa Page from Oak Ridge National Laboratory. ORNL performed measurements and arrived at values for the total effective conductivity of these five different specimens. These numbers will be compared to effective conductivities arrived at using the analytical model derived at MIT. Density measurements and average cell diameter determination are presently under way.

TASK B2. EXISTING MATERIALS/TEST PROCEDURES

\subsection{TEST PROCEDURE FOR HIGH R, SUPER INSULATION}

T. G. Kollie and K. W. Childs

Oak Ridge National Laboratory

Oak Ridge, Tennessee 37831-6092

Measurement of the $R$ of high resistance materials, such as Powder Evacuated Panels (PEPS), in the R-Matic is often limited by specimen size requirements. Usually, the high $R$ specimens are placed in the center of another material of known $R$, and the $R$ of the resulting composite is measured in the R-Matic. Because heat flow is not onedimensional, the HEATING-7 finite-difference, heat-transfer code is used at ORNL to compute $R$ of the high-R material. One of the major disadvantages of this approach is the need to have experienced programmers model the composite and run HEATING-7 on a iarge, batchtype, super-computer such as a cray. To overcome this disadvantage, we are attempting to condense HEATING-7 so that it can run on an IBMcompatible, $386 \mathrm{SX}$ personal computer. In addition, an interface program is being written to allow the program to be menu-driven, automatically 
asking the necessary questions of the operator to set up the heat transfer model. Although the computation times for solutions will be about 12 times as long and require about 2 hours of 386SX time, this approach will allow essentially any laboratory equipped with an R-Matic and $386 \mathrm{SX}$ (a very common IBM-compatible computer) to obtain correct solutions for the $R$ of the unknown in the composite.

\title{
2.2 SUPPORT SERVICES TO INDUSTRY \& DOE
}

\subsubsection{ORNL Activities}

\author{
R. S. Graves, D. W. Yarbrough, and T. G. Kollie \\ Oak Ridge National Laboratory \\ Oak Ridge, Tennessee 37831-6092.
}

R. S. Graves (ORNL) and D. C. Wysocki (Mobay) are Co-Chairmen of the ASTM C 16 Second Symposium on Insulation Materials. All manuscripts are due at ASTM by January 2, 1991, to allow the Symposium proceedings to be available in 0ctober i991. With the help of the session chairmen, reviewers for the manuscripts have been selected and the reviewer 1 ist was submitited to ASTM on November 20, 1990. The review process will begin as soon as papers are received.

R. S. Graves presented a talk entitled, "The Effect of Compression on the Material R-Value of Fiberglass Batt Insulation," at the Conference on Fire Safety and Thermal Insulation held in St. Petersburg, Florida on November 5-6, 1990. An invited talk was given at the Building Thermal Envelope Coordinating Council (BTECC) Symposium on November 7, 1990, in Washington, D.C. This talk was entitled, "CFC Alternatives for ClosedCell Foam Insulation."

R. S. Graves presided over the technical committee meeting for the Insulation Contractors Association of America on November 8, 1990, in Washington, D.C.

The second high-capacity, temperature-controlled fluid circulating bath was obtained for the Unguarded Thin-Heater Apparatus (UTHA). Both circulators were installed to extend the temperature range of the UTHA.

Four heat flux transducers (HFTs) were calibrated for Jeff Christian. Two of these were embedded in Dow Styrofoam and two were embedded in Owens-Corning Fiberglas, Warm-N-Dri, high-density fiberglass. Four specimens were received from the Lawrence Berkeley Laboratories (LBL) and were tested in the heat flow meter apparatus (HFMA). Three of the specimens contain packets filled with argon or krypton. A letter report will be prepared to report the results of LBL. 


\subsubsection{Thermal Resistance Measurements and Data Base of CFC-Replacement Thermal Properties for Foam Insulation Products \\ R. Zarr \\ National Institute of Standards and Technology Gaithersburg, Maryland 20899}

ORNL./IA-21513/28

Progress Report for October 1990:

FY 1990 Milestone 3 (Final Report). A progress report for NIST's foam advisory panel was presented at the ASTM C 16 meeting in New Orleans. At the conclusion of the presentation, a brief proposal outlining future work was distributed. Essentially, NIST is proposing to investigate the influence of edge effects at larye thicknesses on the one-dimensional heat flow within the meter areas of all apparatuses used within the present study. NIST would use Peavy and Rennex's solution to the boundary value problem for an infinite slab between constant temperature, parallel plates within a convective ambient. Additionally, NiST would calibrate both heat-flow-meter apparatuses as a function of thermal resistance. Response by industry has been favorable and this direction will be suggested to DOE.

The remaining work effort for this month was diverted to the 1990 ASTM C 687 Loose-Fill Round Robin.

(1) Measurements of apparent thermal conductivity were conducted using the NIST one-meter guarded hot plate (GHP). Two measurements at a mean temperature of 23.8 degrees Celsius of cellulose loose-fill specimens were conducted. At the conclusion of the GHP tests, the apparent thermal conductivity of the specimens was determined in the large heat-flow-meter apparatus under the same test conditions.

(2) All measurements to date - 3 for glass-fiber batt, 3 for unbonded glass, 3 for rockwool, and 2 for cellulose - were summarized and reported to Dr. David Smith at NIST in Boulder, Colorado.

FY 1989 Task B. Milestone 3 (Round-Robin with ORNL and JWRC). Draft 2 of, "Interlaboratory Comparison of ASTM C 518 Apparatus on Prototypical Polyisocyanurate Boards Foamed with CFC-11," was received from ORNL. This draft was submitted to NIST's Washington Editorial Review Board. Comments from NIST reviewers were reported to ORNL at ASTM C 16 at New Orleans. 


\section{B3. BUILDING MATERIALS PROGRAM MANAGEMENT SUPPORT}

\subsection{MANAGEMENT - ORNL}

Dr. David L. McElroy retired on November 16, 1990, as Group Leader of the Building Materials Group of the Metals and Ceramics Division of ORNL, and Technical Field Manager of the Materials Project of the BTESM Program. Dr. Thomas G. (Tom) Kollie replaced Dr. McElroy in both capacities. Tom has been a member of the Building Materials Group for two years. He began his career in 1960 working for Dr. McElroy in the Physical Properties Group, the predecessor of the Building Materials Group. After 14 years, Tom left the Physical Properties Group to assist in application of thermocouple thermometry for measurements of temperature excursions in simulated loss-of-coolant accidents in nuclear reactors. In 1977, Tom transferred to the $\mathrm{Y}-12 \mathrm{Plant}$, where he was Group Leader of the Metallurgical Engineering Group, whose mission was to develop fabrication technology for nuclear weapons components. In 1988, Tom rejoined ORNL and served for one year as the technical field manager of the Materials Project of tire Energy Conversion and UtiTization Technology Program. 


\section{BUILDING ENVELOPE SYSTEMS}

ORNL Staff:

J. E. Christian, K. E. Wilkes, R. L. Wendt,

G. E. Courville, P. W. Childs, and K. W. Childs

This task inciudes work done at ORNL and work by others on DOE-funded projects on Building Envelope Systems and is divided into Wall

Performance, Advanced Wall Systems, Foundation Systems, Roof Systems, and Building Diagnostics. Each of these project areas is treated separately on the following pages. 


\title{
WALL PERFORMANCE
}

1. THERMAL MASS SIMPLIFIED DESIGN TOOL ASSESSMENT

\author{
J. E. Christian \\ Oak Ridge National Laboratory \\ Oak Ridge, Tennessee 37831-6070
}

No significant progress for the month of November. 


\title{
2. DYNAMIC EVALUATION OF THERMAL BRIDGES
}

\author{
D. Burch \\ National Institute of Standards and Technology \\ Gaithersburg, MD
}

ORNL/IA-21513/28

\section{Progress Report for October 1990:}

FY 1989 Milestone 3 . The final report for this project, entitled, "Dynamic Evaluation of Thermal Bridges in a Typical Office Building," is undergoing review at the National Institute of Standards and Technology. All other milestones for this project have been completed.

In this report, a finite-difference model is used to predict the steadystate and dynamic thermal performance of thermal bridges in a typical office building. The thermal bridges evaluated include: a built-up roof system with ceiling fasteners, a roof/wall interface, an insulated masonry cavity wall with metal studs, a floor slab that penetrates wall insulation, and a window frame/wall interface.

The steady-state analysis reveals that these typical thermal bridges increased the overall envelope heat transfer coefficient for the office building by $33 \%$. A thermal bridge is found to have a large effect when it has a large cross sectional area that short circuits the thermal insulation of the building envelope.

In the dynamic analysis, a finite-difference model is used to numerically determine a complete set of conduction transfer function (CTF) coefficients for each of the thermal bridges. The mathematical procedure is to predict the heat transfer response of a thermal bridge when it is excited by a ramp excitation function. The heat transfer response for a triangular pulse is subsequently obtained by superimposing the responses for three ramp excitation functions to form a triangular pulse. A recursive relation is subsequently applied to the triangular-pulse response to determine first-order CTF coefficients. The validity of the CTF coefficients is demonstrated by accurately predicting the heat transfer response of each of the thermal bridges to a diurnal excitation function.

During the review of this report, a mathematical procedure was offered by a reviewer that permits the effect of the air film resistances to be removed from the CTF coefficients. In this study, procedures to obtain air-to-air CTF coefficients were originally developed. Computer programs such as TARP, BLAST, etc., require surface-to-surface CTF coefficients. This new contribution would permit the CTF coefficients for thermal bridges to be incorporated into computer programs such as TARP, BLAST, etc. The validity of this mathematical procedure is currently being checked out. 
3. VALIDATION OF MOISTURE-TRANSFER MODEL

\author{
D. Burch \\ National Institute of Standards and Technology \\ Gaithersburg, Maryland 20899
}

ORNL/1A-21513/28

Progress Report for October 1990:

FY 1990 Milestone 3 (Complete Final Report on Sensitivity Analysis): A final report entitled, "An Analysis of Moisture Accumulation in a WoodFrame Cavity Wall Subjected to Winter Climate," is undergoing review at the National Institute of Standards and Technology.

Milestones 1 and 2 (Complete Diffusion and Sorption Isotherm Measurements for Ten Materials. NIST is carrying out moisture diffusion property measurements for ten common building materials. The ten materials include: (1) plain gypsum board, (2) white pine, (3) vinylcovered gypsum board, (4) asphalt-impregnated kraft paper, (5) wafer board siding with latex paint applied to the exterior surface, (6) "foam core" sheathing, (7) wood fiber board, (8) exterior AC plywood, (9) thick pressboard, and (10) asphalt-impregnated sheathing.

These property measurements are needed as inputs to the NIST Moisture Transfer Model. The model will be used to recommend good practices for controlling moisture in wall constructions as a function of indoor humidity and outdoor climatic conditions. The measurements are described below.

\title{
Sorption I sotherm Mea surements
}

A sorption isotherm is a plot of the equilibrium moisture content of a material versus ambient relative humidity. These measurements are accomplished by placing small specimens of the materials in pint-size jars above saturated salt-in-water solutions that give different known ambient relative humidities. The specimens are permitted to remain in the jars until the moisture uptake reaches a steady amount called the equilibrium moisture content. Separate sorption isotherms are obtained for specimens initially dry (adsorption isotherm) and for specimens initially saturated (desorption isotherm).

As of the date of this progress report, materials (1) through (7) have been completed. Materials (8) through (10) are currently under way.

\section{Permeability Measurements}

For these measurements, 6-in.-diameter specimens of the materials are installed in a series of glass permeability cups (similar to an ASTM permeance cup) above a saturated salt-in-water solution that exposes the 
lower surface of the specimens to a particular ambient relative humidity. These permeability cups are placed inside glass desiccators above different salt-in-water solutions that expose the upper surface of the specimens to a different relative humidity. In the series of permeability cups, small relative humidity differences are maintained across the specimens covering the humidity range from $0 \%$ to $100 \%$.

The relative humidity difference across the specimens causes water vapor to be transferred through the specimens. The water vapor transfer rate through each specimen is measured by periodically weighing the cup. The permeance is determined by dividing the measured water vapor transfer rate by the exposed surface area and the water vapor pressure

difference. Special analys is procedures are utilized to subtract out the effect of the air film resistances. Permeability for each materia? is plotted as a function of the average relative humidity maintained across the specimen. Separate measurements are carried out at mean temperatures of $75^{\circ} \mathrm{F}$ and $44^{\circ} \mathrm{F}$.

As of the date of this reporting period, materials (1) through (7) have been completed.

\title{
ADVANCED WALL SYSTEMS
}

\author{
1. MOISTURE CONTROL HANDBOOK \\ Joseph Lstiburek \\ Dames \& Hoore, Trow \\ Park Ridge, 111 inois 60068 \\ ORNL/SUb-SD350/6
}

\begin{abstract}
Most of the second draft of the Moisture Control Handbook, "New LowRise, Residential Construction," arrived at ORNL on December 7, 1990. The changes suggested by the review committee in June 1990 have been incorporated. An introductory section, "How to Use this Handbook, "and an executive summary was to follow shortly; after which the Moisture Control Review Committee will be sent copies and offered an opportunity to provide final comments.
\end{abstract}




\title{
FOUNDATION SYSTEMS
}

\section{BUILDING FOUNDATIONS RESEARCH AGENDA}

\author{
J. E. Christian \\ Oak Ridge National Laboratory \\ Oak Ridge, Tennessee 37831-6070
}

Construction has begun on the four foundation test sections in the Envelope Systems Research Apparatus. The heat flux transducer guards for eight transducers have been assembled and calibrated by Ron Graves using the ORNL thin screen tester. Thermocouples have been installed in the interior insulated frame wall test section. Outside damp-proofing materials and all the insulation is on site. Protection boards have been ordered but have not arrived. These will be used to cover the exterior insulation that extends above grade.

\section{SLAB FOUNDATION BENCHMARK MODEL}

D. Wasserman, J. E. Christian, and K. E. Wilkes

Oak Ridge National Laboratory

Oak Ridge, Tennessee 37831-6070

No significant progress to report for the month of November.

3. FOUNDATION THERMAL PERFORMANCE SIMPLIFIED PREDICTION TOOL

Jeff Christian

Oak Ridge National Laboratory

Oak Ridge, Tennessee 37831-6070

No significant progress to report for the month of November. 
ROUF_SYSTEMS

\title{
1. ROOFING RESEARCH CENTER
}

\author{
R. L. Wendt and J. E. Christian \\ Oak Ridge National Laboratory \\ Oak Ridge, Tennessee 37831-6070
}

\begin{abstract}
The Cooperative Research and Development Agreement (CRADA) projects initiated by the Center in September were approved by DOE. One covers additional work on polyisocyanurate insulations developed under the joint government/industry research project. The other was to test the performance of cellulose insulation in the Attic Test Module and LSCS under severe winter conditions.
\end{abstract}

R. L. Wendt accepted an offer from the K-25 Site in Oak Ridge to become their Facilities Manager effective January 1, 1991. Work previously handled by Wendt will be shifted to other Energy Division staff.

The Single Ply Roofing Institutes Technical Committee's Recover Subcommittee requested that $R$. L. Wendt prepare a preliminary proposal for review to determine the rate of change in moisture content of $10 \mathrm{w}-$ slope roof systems that have become wet and are then recovered with new membranes. Knowing the "drying rate" of various systems and the parameters that impact it could lead to significantly more prudent decision making with regard to when it is appropriate to recover existing roofs. It is envisioned that this iroject would be accomplished as an industry/government collaborative research project. This proposal is to be presented to the SPRI Board of Directors at their next meeting.

The RTRA summer data letter report on the Radiation Control Coating (RCC) was reviewed. It provides detailed data of the RCC over 1.5 in. plywood compared to a plain black EPDM over 1.5 in. plywood, but also is compared to R-18 insulated roof system under a plain black and plain white EPDM. Hourly tabulated data are provided in anticipation of its use to validate algorithms in whole building energy simulation models. The field data derived thermal physical properties measurements of the plywood were compared with data collected in the laboratory using the thin screen tester, and the predictions of specific heats agree remarkably wel1. The $k$-values as a function of mean weekly temperature do not agree as well. The field data suggest the in-situ k-value is effected more strongly by mean plywood temperature than that observed in the laboratory under steady-state measurement conditions. 


\section{LARGE SCALE CLIMATE SIMULATOR}

\section{P. H. Childs, K. E. Wilkes, and J. E. Christian Cak Ridge National Laboratory Oak Ridge, Tennessee 37831-6070}

An estimate has been received from Jacques Bodine of Vista Scientific for modifying the LSCS refrigeration loop. A contract is being drafted to initiate this modification. It is hoped that this work can be conducted in early 1991.

The large single-stage compressor cannot continue running at the unloaded conditions that we normally operate under. The rings, as well as two pistons, were replaced. The compressor was then reassembled and appears to function properly.

The loose-fill fiberglass insulation was removed from the Attic Test Apparatus and new insulation of the same type was blown in. The attic was then placed back in the chamber and testing has begun.

3. IEA AMNEX 19 ON LOW SLOPE ROOF SYSTEMS

George E. Courville

Dak Ridge National Laboratory

Oak Ridge, Terinessee 37831-6070

No progress to report for the month of November. 


\title{
4. ATTIC TESTING IN THE LSCS
}

\section{Kenneth E. Willies and Agnes Delmas \\ Oak Ridge Na:ional Laboratory \\ Oak Ridge, Tennessee 37831-6070}

The first sample of fibrous glass loose-fill insulation has been removed, and a second sample has been blown into the attic test module. Testing of this sample was initiated near the end of November. It is planned to repeat most of the tests that were performed with the first sample.

Attic Seal, Inc., has defined a new series of testing on their products based on the findings from the initial testing.

\section{FIELD TESTING OF ISOCYANURATE FOAMS WITH ALTERNATE BLOWING AGENTS}

\author{
J. E. Christian and G. E. Courville \\ Oak Ridge National Laboratory \\ Oak Ridge, Tennessee 37831-6070
}

An ASTM technical paper was prepared on the in-situ and thin-specimen aging of experimental polisocyanurate roof insulation blown with HCFCs. Field data collected on the RTRA have been znalyzed up to December 2, 1990. All of the samples have been reinstalled after being pulled for recalibration checks of the heat fiux transducers in the laboratory. One inturesting observation from the HCFC-14lb specimens under the black and white EPDM is that the field measurements detect a separation of the thermal performance after showing essentially no differences all summer. The laboratory measurements taken three weeks after this apparent difference occurred suggest that once taken out and allowed to come to equilibrium in the laboratory, no measurable $k$-value difference is detected. A physical explanation for the field measurement behavior has not been found; although all of the differences occurred in the top board under the black membrane in the form of a very rapid drop in weekly average k-values. The blends continue to show little thermal performance differences.

The pure blowing agent sample $k$-values predicted by the laboratory slicing analysis for one year of age made at 200 days of age were compared to the actual measured values and found to be within \pm 1.5 percent time $0.5 /$ thickness. 


\title{
6. ROOF MECHANICAL PROPERTIES RESEARCH APPR?ATUS
}

\author{
Robert L. Wendt \\ Oak Ridge National Laboratory \\ Oak Ridge, Tennessee 37831-6070
}

The roof containing the five different polyisocyanurate insulation formulations was installed June 26-27, 1990. Three blisters have been previously noted on the roof platform. They have remained stable in size during November. Tom Smith, NRCA, provided blister vents to be installed in an attempt to shrink the size of the blisters. Joe Hagan, Celotex, visited the site prior to the installation of these vents and requested that the gas in the blisters be sampled prior to installing the vents. This sampling would identify whether or not the blowing agent is contributing to the formation of these blisters. No further work has been accomplished pending the resolve of how to acquire the samples and where they should be sent for analysis.

Site grading was completed. Work remaining to be accomplished includes the installation of the initial series of foundation experiments.

\section{ROOFING INDUSTRY COMMITTEE ON WIND ISSUES}

\author{
George E. Courville \\ Oak Ridge National Laboratory \\ Oak Ridge, Tennessee 37830-6070
}

No progress to report for the month of November. 


\title{
D. COOPERATIVE PROJECTS
}

\section{COOPERATIVE INDUSTRY/GOVERNMENT RESEARCH PROJECT ON ALTERNATIVE BLOWING AGENTS}

\author{
G. E. Courville, D. L. McElroy, J. E. Christian, and R. L. Wendt \\ Oak Ridge National Laboratory \\ Oak Ridge, Tennessee 37831
}

This project is jointly supported by the Department of Energy, the Environmental Protection Agency, The Society of the Plastics Industry, the Polyisocyanurate Insulation Manufacturers Association, and the National Roofing Contractors Association. The objective of the project is to conduct comparative laboratory and field studies of isocyanurate foam roofing boards blown with conventional CFC-11 and with alternative blowing agents. The purpose is to identify performance differences, if any, between foams with alternative blowing agents and foam blown with CFC-11.

\section{MEETINGS AND PRESENTATIONS}

The minutes of the Cooperative/Government Program Steering Committee meeting held on October 4, 1990, in Orlando, Florida, were distributed to participants and a copy of the third draft of, "Laboratory Test Results on the Thermal Resistance of Polyisocyanurate Foam Board Insulation Blown with CFC-11 Substitutes - A Cooperative Industry/ Government Project" (ORNL/TM-11645), was attached for review.

The first meeting of a task group to develop an aging model for foam aging was held on Navember 29, 1990, in conjunction with the CFCAlternatives Conference in Baltimore. The group's objective is a computer code for the thermal performance of foamboard insulations with time. The validation of one-dimensional calculations, reconciliation of $1 \mathrm{ab}$ and field measurements, extension of calculations to three dimensions, and inclusion of facing material were identified as priority topics.

\section{LABORATORY TESTING}

Thermal conductivity tests were completed on the RTRA panels which were blown with CFC-11, HCFC-123, and HCFC-141b (two membranes). These panels are approximately 520 days of age and have now experienced about 430 days of RTRA exposure. Data were obtained in both the Unguarded Thin-Heater Apparatus (UTHA) and the ORNL heat flow meter apparatus (HFMA). These data can be represented with the expression $k=A+B+C / t$, and the absolute average percent deviation does not exceed $0.7 \%$ for any data set. The maximum deviation of any single datum is $1.4 \%$. The order of the thermal conductivity (CFC-11, HCFC-123, HCFC-141b) has not changed. The heat flux transducers were recalibrated and were within $1 \%$ of previous values. 
Draft three of, "Interlaboratory Comparison of Four Heat Flow Meter Apparatuses on Planed Polyisocyanurate Boards Foamed with CFC-11" (ORNL/TM-11720), was prepared and now contains new values for thermal conductance. The document has been sent to all authors and to four reviewers.

\section{FIELD TESTING}

An ASTM technical paper was prepared on the in-situ and thinspecimen aging of experimental polisocyanurate roof insulation blown with HCFCs. Field data collected on the RTRA have been analyzed up to December 2, 1990. All of the samples have been reinstalled after being pulled for recalibration checks of the heat flux transducers in the laboratory. One interesting observation from the HCFC-141b specimens under the black and white EPDM is that the field measurements detect a separation of the thermal performance after showing essentially no differences all summer. The laboratory measurements taken three weeks after this apparent difference occurred suggest that once taken out and allowed to come to equilibrium in the laboratory, no measurable $k$-value difference is detected. A physical explanation for the field measurement behavior has not been found; although all of the differences occurred in the top board under the black membrane in the form of a very rapid drop in weekly average k-values. The blends continue to show little thermal performance differences.

The pure blowing agent sample $k$-values predicted by the laboratory slicing analysis for one year of age made at 200 days of age were compared to the actual measured values and found to be within \pm 1.5 percent time $0.5 /$ thickness.

\section{ROOF MECHANICAL PROPERTIES RESEARCH APPARATUS}

The roof containing the five different polyisocyanurate insulation formulations was installed June 26-27, 1990. Three blisters have been previously noted on the roof platform. They have remained stable in size during November. Tom Smith, NRCA, provided blister vents to be installed in an attempt to shrink the size of the blisters. Joe Hagan, Celotex, visited the site prior to the installation of these vents and requested that the gas in the blisters be sampled prior to installing the vents. This sampling would identify whether or not the blowing agent is contributing to the formation of these blisters. No further work has been accomplished pending the resolve of how to acquire the samples and where they should be sent for analysis.

Site grading was completed. Work remaining to be accomplished includes the installation of the initial series of foundation experiments. 

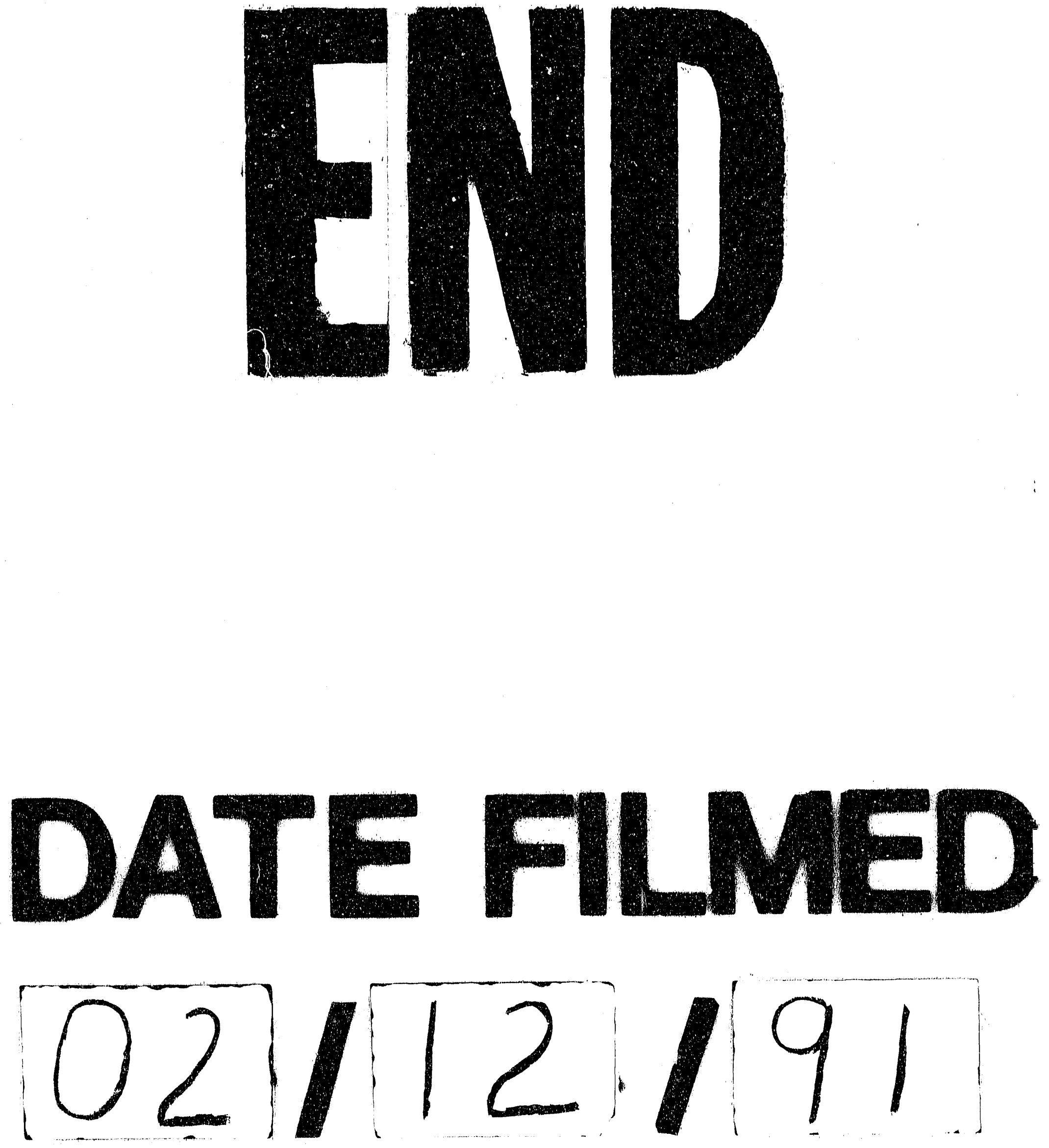
